\title{
Ocimum Species: Ethnomedicinal Uses, Phytochemistry and Pharmacological Importance
}

\author{
Enegide Chinedu ${ }^{1}$, Ofili Charles $C^{2}$
}

\author{
${ }^{1}$ Department of Pharmacology, Novena University, Ogume, Delta State, Nigeria \\ ${ }^{2}$ Department of Public and Community Health, Novena University, Ogume, Delta State, Nigeria
}

\begin{abstract}
Plant species belonging to the Ocimum genus are among the most popular medicinal plants and are being used for several purposes in ethnomedicine. Ocimum is universally cultivated; however, the geographical distribution highlights three major centers of Ocimum diversity: the tropical areas of America, the tropical region of Asia, and the tropical and subtropical regions of Africa. Ocimum species have been employed traditionally for several medicinal purposes, including antioxidant, antibacterial, hypoglycaemic, hepatoprotective, antiviral, and other medicinal purposes. Though scientists have carried out studies and chronicled the pharmacological potentials of Ocimum species, documents containing these data seem to be disassembled, making it difficult to really distinguish the pharmacologically beneficial species from those that are not and also to get comprehensive information about the medicinal species in this genus. Hence, this review aims to outline classified information on the ethnopharmacology, phytochemistry, and pharmacological importance of some Ocimum species that have been different researchers have reported In carrying out this review, the literature search was done via relevant databases including PubMed, Springer, Web of Science, Science Direct, Embase, SciFinder, Google Scholar, and Scopus. The species reviewed are the most widely used from the Ocimum genus in traditional medicine, and they are also the most researched for intended use in conventional therapeutic practice. Literature reveals that these species contain several compounds responsible for the numerous pharmacological activities elicited by them, including antimalarial, anticancer, antidiabetic, anti-inflammatory, and antioxidant effects.
\end{abstract}

KEYWORDS: Ocimum species; Ethnomedicine; Pharmacological potential

\section{INTRODUCTION}

I $\mathrm{n}$ the past few years, scientists and researchers have focused mainly on natural products searching for potent and safer agents for curative, prophylactic, and other medicinal purposes.[1] This has led to extensive scientific studies on suspected medicinal plants and other natural products. [2] Scientific chronicles have shown that remarkable success has evolved from this trend, as several pharmacological agents currently in use were developed from natural products (including plants).[3]

Plant species belonging to the Ocimum genus are among the most popular medicinal plants and are being used for several purposes in ethnomedicine. Of the entire genus stemming from the subfamily Nepetoideae (under the family
Lamiaceae), Ocimum (also known as Basil) is the most important.[4] The name Ocimum was derived from the word "Ozo" (Greek), which means smell.[5] Due to its enormous use in traditional medicine and pharmaceutical industry and perfumery purposes, it is also referred to as the "king of herbs." [6] According to the report documented by Pushpangadan and Bradu, the genus Ocimum with over 160 species, is said to be the largest genera belonging to the Lamiaceae family.[7] About 65 of the species are native to Ocimum, while the others are considered synonyms.[1, 7] Ocimum is universally cultivated; however, the geographical distribution highlights three important centers of Ocimum diversity. These are the tropical areas of America, the tropical region of Asia, and Africa's tropical and subtropical regions. The African tropical rain forest has the highest

\begin{tabular}{|ll|}
\hline & \\
\end{tabular}


number of Ocimum species. [8] The main species of Ocimum with documented pharmacological activity include Ocimum gratissimum, Ocimum basilicum, Ocimum sanctum, Ocimum americanum, and Ocimum Kilimandscharicum. These species have been reported traditionally to possess different culinary and medicinal activities. In different parts of the world, people employ plant species from this genus for several medicinal purposes such as antioxidant, antibacterial, hypoglycaemic, hepatoprotective, antiviral, and several other medicinal purposes. [9 - 12] Though scientists have carried out studies and chronicled the pharmacological potentials Ocimum, documents containing these data seem to be disassembled, making it difficult to really distinguish the pharmacologically beneficial species from those that are not and also to get comprehensive information about the medicinal species in this genus. Hence, this review aims to outline classified information on the ethnopharmacology, phytochemistry, and pharmacological importance of some Ocimum species that have been different researchers have reported

In carrying out this review, the literature search was done via relevant databases, including
PubMed, Springer, Web of Science, Science Direct, Embase, SciFinder, Google Scholar, and Scopus. The keywords used for the search include Ocimum, Ocimum species, phytochemical, phytochemistry, pharmacological activity, pharmacological evaluation of extracts, fractions, or isolated compounds from Ocimum. The study's selection and inclusion were based on publications done in the English language only. All selected manuscripts were analyzed for relevance to the topic, reported plant species, isolated chemical compounds, and evaluated biological activities.

\section{Ethnopharmacology of Ocimum species}

Literature shows that traditionally, plant species belonging to the Ocimum genus are widely employed to treat and manage several ailments, including mental illness, diarrhea, measles, gonorrhea, rheumatism, paralysis, high fever, influenza, epilepsy, abdominal pains, cold, and cough. In addition, they are also used as antipyretic, antihelmintic, antiemetic, and antimalarial agents traditionally. [13 - 14] The specific documented tradomedical application of the different species belonging to the Ocimum genus are summarized in table 1 below.

Table 1. The tradomedical uses of different Ocimum species

\begin{tabular}{|c|c|c|c|c|}
\hline Species & Region & Parts & Traditional Uses & References \\
\hline $\begin{array}{l}\text { Ocimum } \\
\text { americanum }\end{array}$ & $\begin{array}{l}\text { China, India, } \\
\text { Thailand, Nigeria, } \\
\text { Cameroon, Mali, } \\
\text { Guinea }\end{array}$ & Leaves & $\begin{array}{l}\text { It is used for treating coughs, bronchial catarrh, ulcers, } \\
\text { haemorrhoids, tuberculosis, stomach pains, ear and eye } \\
\text { ailments. It is also used to lower high blood pressure and treat } \\
\text { constipation, stomach ache, diabetes, diarrhea, dysentery, and } \\
\text { haemorrhoids. }\end{array}$ & [15 - 19] \\
\hline $\begin{array}{l}\text { Ocimum } \\
\text { basilicum }\end{array}$ & $\begin{array}{l}\text { Cameroon, Egypt, } \\
\text { Nigeria, Guinea, } \\
\text { Mali, Rwanda }\end{array}$ & Leaves & $\begin{array}{l}\text { They were used for prophylaxis and treating cardiovascular } \\
\text { disorders, diabetics, aches and pains, cough, headache, } \\
\text { kidney malfunctions, and diarrhea. It is also used to treat skin } \\
\text { infections, snake bites, and insect stings and as a sedative. }\end{array}$ & [20- 23] \\
\hline $\begin{array}{l}\text { Ocimum } \\
\text { gratissimum }\end{array}$ & $\begin{array}{l}\text { India, China, } \\
\text { Nigeria, New } \\
\text { Zealand, Australia }\end{array}$ & $\begin{array}{l}\text { Leaves, } \\
\text { stem, } \\
\text { root, and } \\
\text { flowers }\end{array}$ & $\begin{array}{l}\text { It is used as an antidiabetic, antiseptic, antidiarrhoeal, } \\
\text { antitussive, antihelmintic, antipyretic, antiinflammatory, } \\
\text { antispasmodic, and antimicrobial agent, also used for the } \\
\text { treatment and management of various stomach and kidney } \\
\text { ailments, upper respiratory tract infection, pneumonia, epilepsy, } \\
\text { fever, convulsion, diarrhea, headache, and influenza. }\end{array}$ & {$[27-34]$} \\
\hline $\begin{array}{l}\text { Ocimum } \\
\text { Kilimand- } \\
\text { scharicum }\end{array}$ & $\begin{array}{l}\text { India, Thailand, } \\
\text { Ethiopia, Tanzania, } \\
\text { Kenya, Uganda, } \\
\text { Sudan, Ethiopia }\end{array}$ & Leaves & $\begin{array}{l}\text { It is employed to treat cough, cold, measles, abdominal pain, } \\
\text { measles, diarrhea, and diarrhea. In addition, it is used as an } \\
\text { insect repellant and for storage pest control. }\end{array}$ & [35 - 37] \\
\hline $\begin{array}{l}\text { Ocimum } \\
\text { sanctum }\end{array}$ & $\begin{array}{l}\text { Asia, Africa, } \\
\text { Malaysia, Australia, } \\
\text { United Arab } \\
\text { Emirates }\end{array}$ & Leaves & $\begin{array}{l}\text { It is used traditionally to manage and treat several ailments such } \\
\text { as headache, fever, cough, common cold, flu, sore throat, colic } \\
\text { pain, asthma, diarrhea, digestive disorders, bronchitis, influenza, } \\
\text { insomnia, hepatic diseases, arthritis, and malaria fever. It is also } \\
\text { used as an antidote for scorpion sting and snakebite }\end{array}$ & {$[38-40]$} \\
\hline
\end{tabular}




\section{Phytochemical Studies}

Ethnomedicinal plants contain complex plant chemicals, also known as phytochemicals. These phytochemicals are made up of several compounds. The enormous information revealed by the ethnomedicinal applications of Ocimum species spurred a scientific investigation into its chemical constituents. These studies have led to the identification and isolation of divers phytochemicals from different plant parts of Ocimum species. These include alkaloids, terpenoids, organic acids, tannins, flavonoids, coumarins, quinones, polyphenols, saponins, and their derivatives.

Ocimum americanum : Phytochemical analysis carried out by Dhale et al. [41] showed that Ocimum americanum is rich in alkaloids, phenolic compounds, tannins, lignin, saponins, flavonoids, terpenoid, and anthraquinone. Alciléia et al. [42] also gave a similar report, and as well documented compounds such as a-pinene, Camphene, sabinene, $\beta$-pinene, $\beta$-mircene, and other compounds which have been identified and isolated from its essential oil.

Ocimum basilicum: Sanni et al. [43] and Ismail[44] reported carbohydrates, tannins, cardiac glycosides, flavonoids, terpenes, and steroids in Ocimum basilicum leaves. Using a GC-MS, Andrew et al. [45] carried out a chemical analysis that showed a-Pinene, $\beta .-$ Myrcene, 4-Hexen-1-ol acetate, and other important bioactive compounds in its essential leaf oil. Sarfaraz et al. [46] also documented the presence of these compounds in a report on their analysis.
Ocimum gratissimum : A phytochemical report documented by Offiah and Chikwendu[47] revealed tannins, steroids, triterpenoids, and carbohydrates in Ocimum gratissimum. Prabhu et al. [48] also showed alkaloids, tannins, flavonoids, and oligosaccharides. Pandey and Chowdhury, [49] Matasyoh et al., [50] Kéita et al.,[51] and Jirovetz et al. [52] have also documented specific compounds which have been isolated from Ocimum gratissimum, this has been summarized in table 2, and some of the structures shown in figure 1.

Ocimum Kilimandscharicum : According to a report by Tewari et al., [53], alkaloids, glycosides, saponins, flavonoids, phenols, carbohydrates, steroids, protein, and amino acids are among the phytochemicals present in Ocimum Kilimandscharicum. In their work, Charles and Simon[54] isolated seventeen compounds from its essential oil, including a- pinene, Camphene, ß-pinene, and Eugenol [table 2].

Ocimum sanctum : In a research work published by Xia et al., [55], carbohydrates, terpenoids and alkaloids were present in the ethanolic extract of Ocimum sanctum. Similarly, Devendran and Balasubramanian[56] also reported the presence of flavonoids, cardiac glycosides, steroids, saponin and tannins, and carbohydrates terpenoids and alkaloids. Furthermore, using a GC-MS, analysis of the hydroalcoholic extract showed several compounds, including Eugenol and Caryophyllene.

Reported compounds isolated from the various Ocimum species have been outlined in table 2, while some of the structures are shown in figure 1.

Table 2. Compounds isolated from different Ocimum species

\begin{tabular}{|c|c|c|}
\hline Species & Compounds Isolated & Reference \\
\hline $\begin{array}{l}\text { Ocimum } \\
\text { americanum }\end{array}$ & $\begin{array}{l}\alpha \text {-pinene, Camphene, Sabinene, } \beta \text {-pinene, } \beta \text {-mircene, Limonene, } 1,8 \text { cineole, linalool oxide, } \\
\text { Fenchone, Linalool, Camphor, Borneol, } 4 \text {-terpineol, } \alpha \text {-Terpineol, cis-piperitol, Estragole, Eugenol, } \\
\beta \text {-selinene, } \beta \text {-caryophyllene, biciclogermacrene, } \beta \text {-bisabolene. }\end{array}$ & {$[42]$} \\
\hline $\begin{array}{l}\text { Ocimum } \\
\text { basilicum }\end{array}$ & $\begin{array}{l}\text { a-Pinene; } \beta \text {-Myrcene; } 4 \text {-Hexen-1-ol, acetate; } 4 \text { Eucalyptol; cis-Linaloloxide; 1,6-Octadien-3-ol, } \\
\text { 3,7-dimethyl; Methyl ethyl cyclopentene; L-Menthone; L-(-)-menthol; Estragole; N-Cyano-3- } \\
\text { methylbut-2-enamine; Citral; Cyclohexene, 4-methyl-1-(1-methyle thyl); Phenol, 2,3,5-trimethyl; } \\
\text { Eugenol; Formic acid, cyclohexyl ester; Copaene; cis-7,10,13,16-Docosatetraenoic acid, } \\
\text { methyl ester; Neoisolongifolene; trans-a-Bergamotene; Alloaromadendrene; Humulene, beta.- } \\
\text { copaene; beta.-Bisabolene; cis-muurola-3,5-diene; cis-.alpha.-Bisabolene; Nerolidol; trans-4- } \\
\text { Methoxycinnamaldehyde; Benzeneacetic acid,.alpha.-hydrox; Phenylethanolamine; 3-Methyl-2- } \\
\text { phenylindole; N-Benzyl-N-ethyl-p-isopropylbenzamide }\end{array}$ & {$[45-46]$} \\
\hline $\begin{array}{l}\text { Ocimum } \\
\text { gratissimum }\end{array}$ & $\begin{array}{l}\text { Eugenol, methyl eugenol, cis-ocimene, trans-ocimene, pinene, camphor, germacrene-D, trans- } \\
\text { caryophyllene, farnesene and l-bisabolene, Thymol, methyl chavicol, linalool, limonene, methyl } \\
\text { eugenol, } \beta \text {-caryophyllene, farnesene, } \alpha \text {-terpineol, methyl isoeugenol, geraniol, } \alpha \text {-copaene, bisabolol, } \\
\text { fenchone, cubenene, Camphene, T-cadanol, sabinene, myrcene, } \beta \text {-bisoboline, } \alpha \text {-humelene and } \\
\beta \text {-elemene. }\end{array}$ & {$[47-52]$} \\
\hline $\begin{array}{l}\text { Ocimum } \\
\text { Kiliman- } \\
\text { dscharicum }\end{array}$ & $\begin{array}{l}\text { ß-pinene, Myrcene, 1,8-cineole, Limonene, Terpinen-4-ol, } \alpha \text {-terpineol, Bornyl acetate, } \alpha \text {-pinene, } \\
\text { Camphene, Eugenol, } \beta \text {-caryophyllene, } \alpha \text {-humulene, Linalool, Camphor, } \gamma \text {-muurolene, Germacerene } \\
\text { B, Epi- } \alpha \text {-cadinol }\end{array}$ & {$[53-54]$} \\
\hline $\begin{array}{l}\text { Ocimum } \\
\text { sanctum }\end{array}$ & $\begin{array}{l}\text { Eugenol; Cyclohexane, 1,2,4-triethenyl-; Caryophyllene; 10-Heptadecen-8-ynoic acid; Cyclopentane, } \\
\text { cyclopropylidene-; Z,Z-4,16-Octadecadien-1-ol acetate; Benzene methanamine, N,N-a,4- } \\
\text { tetramethyl-; 3'8,8'-trimethoxy-3-piperidyl-2,2'-binaphthalene1,1'4,4'-tetrone; Octadecane, } \\
\text { 1,1-dimethoxy-; Pentanedinitrile, 2-methyl- }\end{array}$ & {$[55-56]$} \\
\hline
\end{tabular}



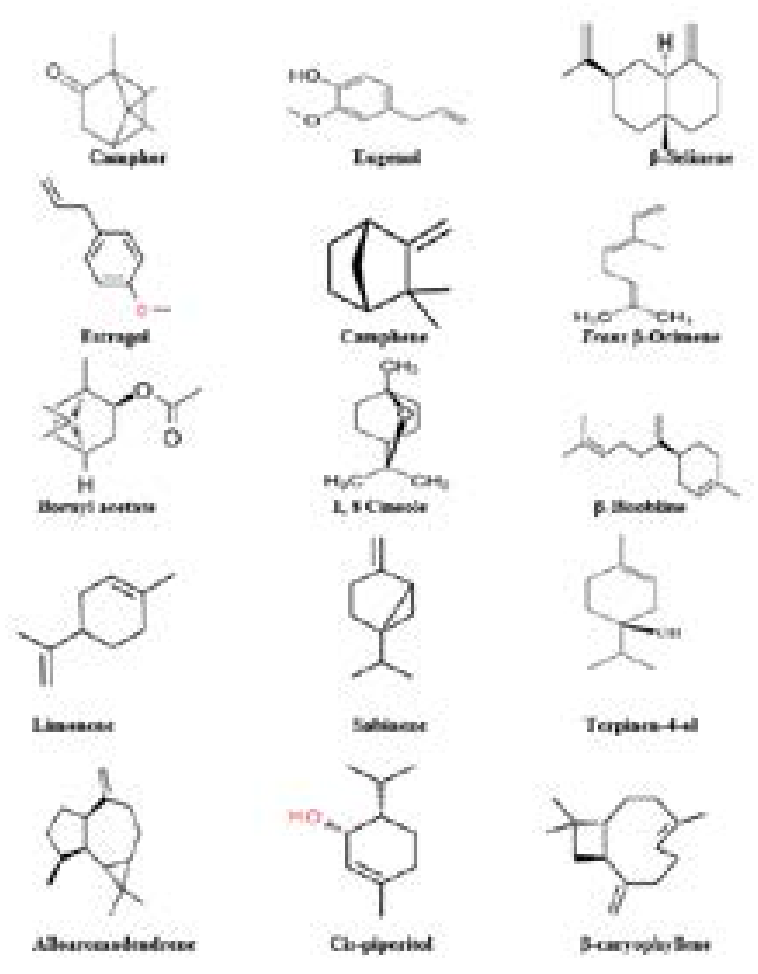

Figure 1. Structures of some compounds identified/ isolated from Ocimum species

\section{Pharmacology}

Several pharmacological studies have confirmed/ establish the efficacy of Ocimum species for their various therapeutic applications.

\section{Ocimum americanum}

Ocimum americanum has been documented to elicit significant antifungal activity,[57 - 59] gastric cytoprotective and antiulcer effect against acute gastric ulcer causative organism,[57 60] wound healing activity,[57] larvicidal and insecticidal activity.[61] The essential oils also have effects such as cytotoxic, antimicrobial, and mosquito repellent effects.[59, 62] The antioxidant activity of Ocimum americanum has also been documented.[63 - 64] Sutilifj et al. reported that Ocimum americanum the whole plant, has a significant hemolytic effect. [65] Sethi et al. documented the antifungal activity of the plant [66], while Priscila et al. reported the bactericidal activity. [67] The antimicrobial activity against gram-positive and gram-negative bacteria has been reported by Thaweboon et al. [68] Aluko et al. also reported its antioxidant effect,[69] Sripriya et al. reported the significant analgesic and anti-inflammatory activities of the leave-in laboratory mice.[70] According to Sinitha et al., Ocimum americanum elicits an immune-modulatory effect [71], while Lenise et al. have also documented its anesthetic activity. [72] Aluko et al. carried out a study to evaluate the hepatoprotective activity of Ocimum americanum leave in laboratory rats with paracetamol-induced liver damage and reported having a hepatoprotective effect.[73]

\section{Ocimum basilicum}

According to Politeo et al. and Ramesh et al., Ocimum basilicum is rich in antioxidants compounds and hence has high antioxidant activity.[74 - 75] Dwivedi et al. stated that the Solvent extracts of the plant elicit significant activity at the cellular level, including inhibition of $\mathrm{HIV}-1$ reverse transcriptase and anti-aggregatory effect on blood platelets.[76] Clinical studies reported by Siurin et al. and Nature et al. revealed that Ocimum basilicum volatile oil has characteristic antioxidant activities.[77 - 78] Bravo et al. also reported the protective activity of the ethanolic extract of Ocimum basilicum against mutagenesis and oxidative DNA damage, accompanied by a decrease in cholesterol synthesis accumulation of lipid in human macro-phages.[79] A report by Wannissorn et al. and Ahmet et al. reveals that Ocimum basilicum exhibits antibacterial effect against several bacteria, including $\mathrm{C}$. perferingens, Salmonella spp., C. jejunii, and E. coli.[80 - 81] Also, Opalchenova and Obreshkova revealed that the plant aerial parts volatile oil elicit significant activity against drug immune clinical isolates of Pseudomonas, Enterococcus, and Staphylococcus.[82] Patel et al. have documented the significant antimicrobial effects of Ocimum basilicum from their study.[83] In vitro studies by Yamasaki, et al. revealed that Ocimum basilicum exhibits marked inhibitory actions against cytopathogenicity induced by HIV-1 in MT-4 cells.[84] Renzulli et al. reported that rosmarinic acid (a compound present in Ocimum basilicum) has significant inhibitory activity against inflammatory processes. In vitro studies reveal that rosmarinic reduces the production of oxygen species and inhibits protein and DNA synthesis induced by mycotoxins, hence preventing cell death. [85] In vitro study on P388 and KB cell lines by Manosroi et al. revealed that the essential oil Ocimum basilicum elicited moderate anti-proliferative activity compared to the standard drug 5-fluorouracil.[86] Mohan et al. reported the hypolipidemic and hypoglycemic activity of aqueous extract of Ocimum basilicum in laboratory rats. They observed a marked reduction in serum lipid, lipid peroxidation products, blood glucose level, and improvement in glucose tolerance.[87]

\section{Ocimum gratissimum}

The antibacterial and antifungal efficacy of Ocimum gratissimum has been reported in various studies.[88 - 89] Pharmacological study of the aqueous extract revealed it has an analgesic effect in mice, stomach strip blocking effect in rats, and inhibitory effect on rabbit jejunum pendular movement. [90] Iwalokun et al. revealed that the oil elicits a significant inhibitory activity against the virulent strains of Shigella, E. coli, and Salmonella.[91] The hexane fraction exhibits a highly significant antimicrobial activity against K. pneumonia and V. cholera.[92] It is significantly active against $\mathrm{P}$. aeruginosa, $\mathrm{S}$. 
Typhi, V. cholera, and N. gonorrhea.[93] It has an excellent synergic activity with ampicillin, eliciting highly significant antibacterial effects against $\mathrm{E}$. coli and $\mathrm{P}$. mirabilis, and also possess similar synergic activity with nystatin and ketoconazole, eliciting significant antifungal effect against C. Albicans.[94] The anti-diarrheal activity of the leaf extract was established in a study by Ilori et al., which used the disc diffusion and tube dilution methods to ascertain its effect against bacteria S. Typhi, E. coli, S. dysenteriae, P. shigelloides, and A. sobria, and it proved to be a significant antibacterial agent.[95] Pratheeba et al. also revealed that the chloroform leaf extract had an excellent insecticidal effect against filariasis causing mosquito vector Culex quinquefasciatus.[96] The plant leaves have been shown to possess a broad-spectrum antibacterial activity against P. mirabilis, E. coli, and S. aureus.[97] The methanolic leaf extract has been reported to be active against nicotine toxicity due to its ability to decrease free radical generation and lipid-protein damage, and antioxidant activity.[98] The aqueous leaf extract has been reported to show significant hypoglycaemic effect, reducing lipid MDA, LDLcholesterol, and triacylglycerol levels [99] and caused a marked decrease in the plasma glucose level in laboratory rats in the streptozotocininduced diabetic model.[100] The aqueous leaf extract has been observed to inhibit proliferation, chemotaxis, induction of COX-2 protein and morphogenesis, and decrease the size of breast cancer tumors.[101] The dichloromethane leaf extract in an in vitro study inhibited myeloid leukemia [102]; hence, it may help treat human cancer. The methanolic crude leaf extract has been documented to be having haematinic and hemopoietic activity in laboratory rats.[103] An increase in erythrocytes, hemoglobin packed cell volume, thrombocytes, and neutrophils count, as well as increase in platelet distribution width, mean platelet volume, and platelet-large cell ratio $(\mathrm{P}-\mathrm{LCR})$ have been observed to be elicited by the leaf extract.[104] Reduction in the serum total protein and urea level, packed cell volume, neutrophils, hemoglobin, and increased uric acid, in total acid, prostatic acid, phosphatases, leucocytes, and lymphocytes have also been reported to be elicited by the plant.[105] Its leaf essential oil has been reported to show both fungistatic and fungicidal activity at different concentrations against A. alternata, S. rolfsii and C. capsici.[106]

\section{Ocimum kilimandscharicum}

Hakkim et al. evaluated the antioxidant potential of the Methanolic leaf extract of Ocimum kilimandscharicum using an in vitro model. They reported it to exhibit a moderate activity compared to butylated hydroxyl anisole (BHA). [107] Mwangi et al. also experimented to examine the antinociceptive activity of the alcoholic leaf extract of Ocimum kilimandscharicum in mice using the tail-flick model. The outcome revealed it to be a significant antinociceptive agent. [108]
Based on their in-vitro antiplasmodial study using dichloromethane extract of leaves and twigs of Ocimum kilimandscharicum, Owuor et al. reported significant activity against both chloroquine-resistant and chloroquine-sensitive Plasmodium parasites, [109]. In contrast, Runyoro et al. reported that the oil elicited larvicidal activity on Culex quinquefasciatus larvae. [110] Using castor-oil-induced diarrhoea model and castor oil-induced enteropooling assay in rats; and charcoal meal test/intestinal motility test in mice, Serin et al. demonstrated that the aqueous leaf extract has significant anti-diarrheal activity. [111] Kumar et al. reported the significant antimicrobial activity of volatile oil of the whole plant of Ocimum kilimandscharicum against Gram-negative bacteria (E. coli, E. cloacae, Vibrio cholera, S. dysenteriae, P. aeruginosa, Klebsiella sp), [112] while Shinde et al. also reported its effectiveness against Gram-positive bacteria (S. aureus, S. epidermidis, S. mutans, S. viridians, B. subtilis, M. luteus). [113] Monga et al. also reported the antimelanoma and radioprotective effect of alcoholic aqueous extract in mice.[114] Jambere et al. carried out a laboratory test on the leaves of Ocimum kilimandscharicum against the following insects Rhyzopertha Dominica, Sitophilus zeamais, Sitotroga cerealella in maize and sorghum grains to evaluate its insecticidal activity. The reported experimental outcome showed it to be an effective insecticidal agent. [115] Mahesh et al. have also documented the significant wound healing activity of the aqueous extract as a result of the experiment they carried out on laboratory rats, using the excision, incision, and dead space wound model.[116]

\section{Ocimum sanctum}

Ocimum sanctum has been chronicled and described to be having several pharmacological activities. Rahman et al. reveals that Ocimum sanctum shows antimicrobial activity against a wide range of bacteria, including Staphylococci sp., E. coli, Shigella sp., S. aureus, Enterobacteria sp., P. aernginosa, S. Typhi, Staphylococci sp., C. Albicans, K. pneumonia, M. tuberculosis, and M. pyogenes. [117] According to an in vitro study by Farivar et al., Ocimum sanctum extract proved to be an effective anti-tuberculosis agent. [118] Khan et al. reported that aqueous, hexane, chloroform, n-butanol extracts, and essential oil of Ocimum sanctum showed significant antifungal activity against several fungi $A$. solani, C. guillermondii, C. capsici, Curvularia sp., F. solani, H. oryzae and A. flavus.[119 - 120] Kelm et al. also reported that the methanolic, hydroalcoholic, and aqueous extracts of Ocimum sanctum elicit significant antioxidant activity, both in vitro and in vivo. [121] According to Geetha et al., Oral intake of the Ocimum sanctum significantly protects the liver and aortic tissue from hypercholesterolemia-induced peroxidative damage.[122] Siva et al. documented that the Oral administration of Ocimum sanctum extract significantly reduced blood sugar levels 
in streptozotocin-induced and glucose-fed hyperglycemic diabetic rats. A different study by Gholap and Kar also showed that Ocimum sanctum reduced the serum concentration of cortisol and glucose and elicited antiperoxidative activity.[123] Aruna et al., in their study, revealed that Ocimum sanctum leaves significantly reduced the squamous cell hematoma incidences and carcinoma in experimental rats. [124] The result from a study by Ganasoundari et al. revealed that Ocimum sanctum aqueous leaf extract inhibited hydroxyl $(\mathrm{OH})$ radicalinduced deoxyribose degeneration significantly. They also showed the synergic activity WR2721 and Ocimum sanctum, which produced a better effect against $\mathrm{OH}$ radical activity when compared with the individual agents alone. [125] Shetty et al. experimented with evaluating the activity of Ocimum sanctum aqueous leaf extract on tumor necrosis factor-Alfa (TNF-Alfa) in laboratory rats, using the excision model. The result showed that the Ocimum sanctum extract increased the rate of epithelization and wound contraction, hence a significant wound healing effect. [126] In the antiulcer study carried out by Govind et al. in rats using aspirin, indomethacin, alcohol (ethanol 50\%), histamine, reserpine, serotonin, or stress-induced ulcers models, the oil of Ocimum sanctum showed significant antiulcer activity. [127] Mediratta et al. reported that steam distilled leave extract of Ocimum sanctum caused a modification in laboratory rat humoral immune response. This could be attributed to antibody production, the release of mediators of hypersensitivity reactions, and tissue responses to mediators in the target organs.[128] Godhwani et al., in a separate experiment, also demonstrated the immunomodulatory effect of Ocimum sanctum using widal and sheep erythrocyte agglutination tests. [129] Sridevi et al. showed that Ocimum sanctum has significant benefits when employed in the treatment of asthma and other related conditions. They also reported that Ocimum sanctum has the potential to cause mast cell stabilization, suppression of IgE, and inhibition of release of inflammatory mediators; hence, it may be the cause of these effects. [130] According to Ravindran et al., the Ocimum sanctum normalizes noise stress-induced alteration in neurotransmitter levels due to, and this is proof of its anti-stress activity. [131] Asha et al. showed the significant antihelmintic activity of Ocimum sanctum essential oil using the Caenorhabditis elegant model.[132] Different extracts of stem and leaves of Ocimum sanctum were subjected to experimental studies for anticonvulsant activity by maximal electroshock model using phenytoin as standard. It was observed that ethanol and chloroform extract of leaf and stem produced significant preventive effects against toxic convulsions induced by trans corneal electroshock. [133] Ocimum sanctum has also been shown to have a robust cardioprotective effect against myocardial agents. Sood et al. revealed that Ocimum sanctum elicited significant protection against isoproterenol-induced myocardial necrosis in laboratory rats by increasing the activity of endogenous antioxidants. [134] Joshi et al. reported that Ocimum sanctum L. alcoholic extract ameliorated scopolamine-induced amnesic effect as well as memory deficits caused by aging in laboratory mice. Ocimum sanctum both increased significantly step-down latency (SDL) and acetylcholine esterase inhibition. This may be useful in the treatment of dementia, Alzheimer's disease, and other cognitive disorders.[135] Ocimum sanctum has been documented to have a significant antidote effect against dog bite, snake bite, scorpion bite, and insect bites.[136]

\section{Conclusion}

Ocimum species have been employed traditionally for therapy globally. The species reviewed are the most widely used from the Ocimum genus in traditional medicine, and they are also the most researched for intended use in conventional therapeutic practice. These species contain several compounds responsible for the numerous pharmacological activities elicited by them, including antimalarial, anticancer, antidiabetic, anti-inflammatory, and antioxidant effects.

\section{Source of Support: Nil}

\section{Conflict of Interest: None Declared}

\section{REFERENCES}

1. Ashraf $\mathrm{K}$, Haque MR, Amir M, Ahmad N, Ahmad W, Sultan S, Ali Shah SA, Mahmoud AA, Mujeeb M, Bin Shafie MF. An overview of phytochemical and biological acitivities: Ficus deltoidea Jack and other Fiscus spp. J Pharm Bioall Sci 2021;13:11-25.

2. Bunawan H, Amin NM, Bunawan SN, Mohd Noor N. Fiscus deltoidea jack: a review on its phytochemistry and pharmacological importance. Evi-Based Comp Alter Med 2014;2:1-8.

3. Chinedu E, Arome D, Ameh SF, Ameh GE. Evaluation of the anti-proliferative and cytostatic effect of Citrus sinensis (orange) fruit juice. Int J App Basic Med Res 2014;4:20-2.

4. Chowdhury T, Mandal A, Roy SC, De Sarker D. Diversity of the genus Ocimum (Lamiaceae) through morpho-molecular (RAPD) and chemical (GC-MS) analysis. J Gen Eng Biotech 2017;15:275-286.

5. Hereman S. Paxton's Botanical Dictionary. Bradbury Evans and Co., London, 1868.

6. Simpson BB, Corner OM. Economic BotanyPlants in our World, McGraw-Hill Book Company, Hamburg, 1986.

7. Pushpangadan P, Bradu BL. In: Chadha KL, 
Gupta R (Eds.), Advances in Horticulture, Malhotra Publishing House, New Delhi, 1995.

8. Paton A, Harley RM, Harley MM. Iin: Hiltunen R, Holm Y. (Eds.), Ocimum: An Overview of Classification and Relationship, Harwood Academic Publishers, Amsterdam, 1999.

9. Sandeep P. The phytochemical constituents, pharmacological and traditional uses of Ocimum gratissimum $\mathrm{L}$ in tropics. Indo Am $\mathrm{P}$ Sci 2017;4(11):4234 - 4242.

10. Nwanjo HU, Oze GO. Hypolipidaemic and antioxidant properties of Ocimum gratissimum on diabetic rats. Plant Prod Res J 2007;11:1-4.

11. Rao SA, Vijay Y, Deepthi T, Lakshmi CS, Rani V. Antidiabetic effect of ethanolic extract of leaves of Ocimum sanctum in alloxan induced diabetes in rats. Int $\mathrm{J}$ Basic Clin Pharmacol 2013;2:613-616.

12. Maddi R, Amani $\mathrm{P}$, Bhavitha S, Gayathri $\mathrm{T}$, Lohitha T. A review on Ocimum species: Ocimum americanum L., Ocimum basilium L., Ocimum gratissimum L. and Ocimum tenuiflorum L. Int $\mathrm{J}$ Res Ayurveda Pharm 2019;10(3):41-48.

13. Nyarko AK, Asare-Anane $\mathrm{H}$, Ofosuhene $\mathrm{M}$, Addy ME. Extract of Ocimum canum lowers blood glucose and facilitates insulin release by isolated pancreatic beta-islet cells. Phytomed 2002;9:346-351.

14. Obeng-Ofori D, Reichmuth $\mathrm{CH}$, Bekele AJ, Has-sanali A. Toxicity and protectant potential of camphor, a major component of essential oil of Ocimum kilimandscharicum, against four stored product beetles. Int J Pest Manag 1998;44:203-209.

15. Pattnaik S, Chand PK. In vitro propagation of the medicinal herbs Ocimum americanumL. syn. O. canum Sims.(hoary Basil) and Ocimum sanctum L.(holy Basil). Plant Cell Reports 1996; 15(11):846-850.

16. Watt JM, Gerdinat M, Breyer-Brandwij K. Medicinal and poisonous plants of southern and eastern africa,. Second Edition. E \& S Lwinstone Ltd; 1962.

17. Githinji CW, Kokwaro JO. Ethnomedicinal study of major species in the family Labiatae from Kenya. Journal of Ethnopharmacology 1993; 39(3):197-203.

18. Kokwaro J. Medicinal Plants of East Africa. Second Edition. Kenya Literature Bureau; 1993.

19. Vidhya E, Vijayakumar S, Rajalakshmi S, Kalaiselvi S, Pandiyan P. Antimicrobial activity and phytochemical screening of Ocimum americanumL extracts against pathogenic microorganisms. Acta Ecologica Sinica 2020; 40(3):214-220.
20. Harnafia H, Azizb M, Amrania S. Sweet basil (Ocimum basilicum L.) improves lipid metabolism in hypercholesterolemic rats. Euro e-Journal Clin Nutri Metabol. 2009; 4:181-6.

21. 21. Umar A, Zhou W, Abdusalam E, Tursun A, Reyim N, Tohti I, Moore N. Effect of Ocimum basilicum L. on cyclo-oxygenase isoforms and prostaglandins involved in thrombosis. J Ethnopharmacol 2014;152: 151-5.

22. Tsai KD, Lin BR, Perng DS, Wei JC, Yu YW, Cherng JM. Immunodulatory effects of aqueous extract of Ocimum basilicum (Linn.) and some of its constituents on human immune cells. J Med Plants Resear 2011;5:1873-83.

23. Opalchenova G, Obreshkova D. Comparative studies on the activity of basil-an essential oil from Ocimum basilicum L. against multidrug resistant clinical isolates of the genera Staphylococcus and Pseudomonas by using different test methods. J Microbiol Methods. 2003; 54: 105-10.

24. Caceres A, Cano O, Samayoa B, Aguilar L. Plants used in Guatemala for the treatment of gastrointestinal disorders. 1. Screening of 84 plants against enterobacteria. J Ethnopharmacol 1990;30:55-73.

25. Ngassoum MB, Ousmaila H, Ngamo LT, Maponmetsem PM, Jirovetz L, Buchbauer G. Aroma compounds of essential oils of two varieties of the spice plant Ocimum canum Sims. From northern Cameroon J Food Comp Anal 2004;17:197-204.

26. Bassole IHN, Guelbeogo WM, Nebie R, Costantini C, Sagnon NF, Kabore ZI, Traore SA. Ovicidal and larvicidal activity against Aedes aegypti and Anopheles gambiae complex mosquitoes of essential oils extracted from three spontaneous plants of Burkina Faso. Parasitol 2003;45:23-26.

27. Adebolu TT, Oladimeji SA. Antimicrobial activity of leaf extracts of Ocimum gratissimum on selected diarrhoea causing bacteria in Southwestern Nigeria. Afri J Biotechnol 2005;4:682-684.

28. Aguiyi JC, Obi E, Gang SS, Igweh A. Hypoglycaemic activity of Ocimum gratissimum in rats. Fitoterapia 2000;71: 444-446.

29. Akinyemi O, Mendie U, Smith S, Oyefolu A, Coker A. Screening of some medical plants for anti-salmonella activity. J Herb Pharmocother 2004;5:45-60.

30. Gbolade AA. Inventory of antidiabetic plants in selected districts of Lagos State, Nigeria. J Ethnopharmacol 2009;121:135-139.

31. Lopez P, Sanchez C, Batlle R, Nerin C. Solid and vapor-phase antimicrobial activities of six essential oils: Susceptibility of selected food- 
borne bacterial and fungi strains. J Agri Food Chem 2005;53:6939-6946.

32. Odukoya A, Ilori O, Sofidiya M, Aniunoh O, Lawal B, Tade I. Antioxidant a c t i v i t y of Nigerian dietary spices. EJEAF Chem 2005;46:1086-1093.

33. 33. Ezekwesili CN, Obiora KA, Ugwu OP. Evaluation of anti-diarrhoeal property of crude aqueous extract of Ocimum gratissimum $\mathrm{L}$. (Labiatae) in rats. Biokemistri 2004;16:122131.

34. Freire MM, Marques OM, Costa M. Effects of seasonal variation on the central nervous system activity of Ocimum gratissimum L. essential oil. J Ethnopharmacol. 2006; 105:161-6.

35. Ofori DO, Reichmuth $\mathrm{CH}$, Bekele AJ, Hassanali A. toxicity and protectant potential of camphor, a major component of essential oil of ocimum kilimandscharicum, against four-stored product beetles. Int $\mathrm{J}$ Pest Manag 1998;44(4):203-209.

36. Bekele J, Hasannali A. Blend effects in the toxicity of the essential oil constituents of ocimum kilimandscharicum and Ocimum kenyense (Labiateae) on two poat-harvest pests. Phytochem 2001;57:385-391.

37. Misra RC, Das G. Ocimum kilimandscharicum Guerke (Lamiaceae): A new distributional record for peninsular India with focus on its economic potential. Proc Natl Acad Sci India Sect B Biol Sci 2016;86:795-803.

38. Pandey G, Madhuri S. Pharmacologocal Activities of Ocimum sanctum (Tulsi): A Review. Int. J.Pharm. Sci. Rev. Res 2010;5(1):61-66.

39. Ogen S, Mas'ud H, Setiawan K, Muchammad Y, Ngakan MRW. Anthelmintic Activity of Basil Leaves (Ocimum sanctum Linn.) Infusion Against Ascaris suum In Vitro. J Parasite Sci 2017;1(2):47-50.

40. Rai V, Mani UV, Iyer UM. Effect of Ocimum sanctum leaf powder on blood lipoproteins, glycated proteins and total Amino acids in patients with Non-insulin-dependent Diabetes Mellitus. J Nutri Environ Med 2009;7: 113-8.

41. Dhale DA, Birari AR, Dhulgande GS. Preliminary Screening of Antibacterial and Phytochemical Studies of Ocimum americanum Linn. J Ecobiotechnol 2010;2(8):11-13.

42. Alciléia NY, Renata G, Aureo TY, Expedito LS, Saulo ES, Marcio JD, Márcia MOD, Ciomar $\mathrm{AB}$, Roberto KNC. Anti-inflammatory Activity of Ocimum americanumL. Essential Oil in Experimental Model of Zymosan-Induced Arthritis. Am J Chin Med 2013; 41(4): 913-926

43. Sanni S, Onyeyili PA, Sanni FS. Phytochemical Analysis, Elemental Determination and Some in vitro Antibacterial Activity of Ocimum basilicum L. Leaf Extracts. Resear J Phytochem, 2008;2:77-83.

44. Ismail $M$. Central properties and chemical composition of Ocimum basilicum essential oil. Pharmaceut Bio 2006; 44(8):619-626.

45. Andrew BF, Felicitas EM, Emrobowansan MI, Anthony JA, Voster M. Phytochemical Constituents and Antioxidant Activity of Sweet Basil (Ocimum basilicum L.) Essential Oil on Ground Beef from Boran and Nguni Cattle. Int J Food Sci 2019;2019:1- 8.

46. Sarfaraz KM , Fazal UR, Muhammad SK, Said G, Naveed A, Ghulam M, Khalid U. Phytochemical Constituents and Pharmacological Activities of Sweet Basil-Ocimum basilicum L. (Lamiaceae). Asian J Chem 2011;23(9):3773-3782

47. Offiah VN, Chikwendu UA. Antidiarrhoeal effects of Ocimum gratissimum leaf extract in experimental animals. J Ethnopharmacol 1999;68:327-30.

48. Prabhu KS, Lobo R, Shirwaikar AA, Shirwaikar A. Ocimum gratissimum: A Review of its Chemical, Pharmacological and Ethnomedicinal Properties. The Open Complem Med J 2009;1:1-15.

49. Pandey AK, Chowdhury AR. Composition of the essential oil of Ocimum gratissimum grown in Madhya Pradesh. J Med Aromat Plant Sci 2000; 22-23, 26-8.

50. Matasyoh LG, Josphat CM, Francis NW, Miriam GK, Anne WTM,Titus KM. Chemical composition and antimicrobial activity of theessential oil of Ocimum gratissimum L. growing in Eastern Kenya.Afr J Biotech 2007; 6: $760-5$.

51. Kéita SK, Vincent C, Jean-Pierre S, Bélanger A. Essential oil composition of Ocimum basilicum L., O. gratissimum L. and O. suave L. in the Republic of Guinea. Flav Fragr J 2000; 5:33941.

52. Jirovetz L, Buchbauer G, Ngassoum MB, Ngamo LT, Adjoudji O. Combined investigation of the chemical composition of essential oils of Ocimum gratissimum and Xylopia aethiopica from Cameroon and their insecticidal activities against stored maize pest Sitophilus zeamais. Ernähr 2005; 29:55-60.

53. Tewari D, Pandey HK, Sah AN, Meena HS, Manchanda A. Pharmacognostical and biochemical investigation of Ocimum kilimandscharicum plants available in western Himalayan region. Asian Journal of Plant Science and Research, 2012, 2 (4):446-451

54. Charles DJ, Simon JE, Essential oil constituents of Ocimum kilimandshcaricum Guerke, J Essential Oil Resear 1992;4:125-128. 
55. Xia KZ, Perveen N, Khan NH. Phytochemical analysis, antibacterial and antioxidant activity determination of Ocimum sanctum. Pharm Pharmacol Int J 2018;6(6):490-497.

56. Devendran G, Balasubramanian U. Qualitative phytochemical screening and GC-MS analysis of Ocimum sanctum L. leaves. Asian J Plant Sci Resear, 2011;1(4):44-48

57. Sutili FJ, Velasquez A, Pinheiro CG, Heinzmann BM, Gatlin III DM, Baldisserotto B. Evaluation of Ocimum americanumessential oil as an additive in red drum (Sciaenops ocellatus) diets. Fish and Shell fish Immunol 2016; 56:155-161.

58. Vidhya E, Vijayakumar S, Rajalakshmi S, Kalaiselvi S, Pandiyan P. Antimicrobial activity and phytochemical screening of Ocimum americanumL extracts against pathogenic microorganisms. Acta Ecologica Sinica 2020; 40(3):214-220.

59. Zengin G, Ferrante C, Gnapi DE, et al. Comprehensive approaches on the chemical constituents and pharmacological properties of flowers and leaves of American Basil (Ocimum americanumL). Food Resear Int 2019; 125: 108610 .

60. Carović-Stanko K, Orlić S, Politeo O, et al. Composition and antibacterial activities of essential oils of seven Ocimum taxa. Food Chem 2010; 119(1):196-201.

61. Shadia E, El-Aziz A, Omer EA, Sabra AS. Chemical composition of Ocimum americanumessential oil and its biological effects against Agrotis ipsilon (Lepidoptera: Noctuidae). Research Journal of Agri Biol Sci 2007;3(6):740-747

62. Runyoro D, Ngassapa O, Vagionas K, Aligiannis N, Graikou K, Chinou I. Chemical composition and antimicrobial activity of the essential oils of four Ocimum species growing in Tanzania. Food Chem 2010; 119(1):311-316.

63. Chokechaijaroenporn O, Bunyapraphatsara $\mathrm{N}$, Kongchuensin S. Mosquito repellent activities of Ocimum volatile oils. Phytomed 1994;1(2):135-139.

64. Madhiyazhagan P, Murugan K, Kumar AN, Nataraj T. Extraction of mosquitocidals from Ocimum canum leaves for the control of dengue and malarial vectors. Asian Pac J Trop Dis 2014; 4:S549-S555.

65. Sutilifj, Velasquez, Pinheiro CG, Baldesserotto, Evaluation of Ocimum americanumessential oil as an additive in red drum (Sciaenops ocellatus) diets, Fish shellfish imunol 2016 Sep; 56:155-161.

66. Sethi S, Prakash Om, Chandra M, Punetha $H$, Pant A K. Antifungal activity of essential oils of some Ocimum species collected from different locations of Uttarakhand, Indian Journal of Natural Product Resources 2013; 4(4):392397.

67. Priscila RN, Vieira Selene Mde, Morais Francisco HQ, Bezerra Pablito Augusto Travassos Ferreira Írvila, ROliveira Maria Goretti V. Silva. Chemical composition and antifungal activity of essential oils from Ocimum species. Industrial Crops and Products 2014 April; 55: 267-271

68. Thaweboon S, Thaweboon $\mathrm{B}$, In vitro antimicrobial activity of Ocimum americanumL. essential oil against oral microorganisms. The Southeast Asian Journal of Tropical Medicine and Pub Heal 2009; 40(5):1025-1033.

69. Aluko BT, Oloyede OI, Afolayan AJ, Polyphenolic contents and free radical scavenging potential of extracts from leaves of Ocimum americanumL. Pakistan Journal of Biological Sciences 2013; 16(1):22-30.

70. Sripriya D, Venkanna L, Estari Mamidala. Analgesic and anti-inflammatory effects of Ocimum americanum(Linn) In Laboratory Animals. IJPSR 201; 2(8) 2121-2125.

71. Sunitha, Nasreen begum. Immunomodulatory activity of methanolic extract of Ocimum americanumseeds. Journal of Pharmaceutical and Biomedical Analysis 2011; 2(1):33-38.

72. Lenise de Lima Silva, Quelen Iane Garlet, Gessi Koakoski, Murilo Sander de Abreu, Carlos Augusto Mallmann, Bernardo Baldisserotto, Leonardo José Gil Barcellos and Berta Maria Heinzmann. Anesthetic activity of the essential oil of Ocimum americanumin Rhamdia quelen (Quoy \& Gaimard, 1824) and its effects on stress parameters. Neotrop Ichthyol 2015; 13(4):715-722.

73. Aluko BT, Oloyede OI, Afolayan AJ. Hepatoprotective activity of Ocimum americanumL leaves against paracetamol induced liver damage in rats. American Journal of Life Sciences 2013 April; 1(2):37-42.

74. Politeo O, Jukic M, Milos M. Chemical composition and antioxidant capacity of free volatile aglycones from Basil (Ocimum basilicum L.) compared with its essential oil. Food Chem. 2007; 101, 379-85.

75. Ramesh B, Satakopan VN. 'In vitro' Antioxidant activities of Ocimum species; Ocimum basilicum L. and Ocimum santum. J. Cell and Tissue Res. 2010; 10: 2145-50.

76. 76. Dwivedi C, Abu-Ghazaleh A. Chemopreventive effects of sandalwood oil on skin papillomas in mice. Eur. J. Cancer Prev. 1997; 6: 399-401.

77. Siurin SA. Effects of essential oil on lipid peroxidation and lipid metabolism in patients with chronic bronchitis. Klin Med (Mosk). 1997; 75: 43-5. 
78. Niture SK, Rao US, Srivenugopal KS. Chemo preventative strategies targeting the MGMT repair protein; augmented expression in human lymphocytes and tumor cells by ethanolic and aqueous extracts of several Indian medicinal plants. Int. J. Oncol. 2006; 29: 1269-78.

79. Bravo E, Amrani S, Aziz M, Harnafi H, Napolitano M. Ocimum basilicumethanolic extract decreases cholesterol synthesis and lipid accumulation in human macrophages. Fitoterapia. 2008; 79: 515-23.

80. Wannissorn B, Jarikasem S, Siriwangchai $\mathrm{T}$, Thubthimthed S. Antibacterial properties of essential oils from Thai medicinal plants. Fitoterapia. 2005; 76: 233-6.

81. Ahmet AZ, Medine GLLCE, Meryem PENGL, Hatice UTC, Fikrettin PAHUN. Üsa K: Antimicrobial Effects of Ocimum basilicum (Labiatae) Extract. Turk. J. Biol. 2005; 29: 155-60.

82. Opalchenova G, Obreshkova D. Comparative studies on the activity of Basil--an essential oil from Ocimum basilicum L.-against multidrug resistant clinical isolates of the genera Staphylococcus, Enterococcus and Pseudomonas by using different test methods. J. Microbiol. Methods. 2003; 54:105-10.

83. Patel VK, Bhatt VH. Folklore therapeutic indigenous plants in periodontal disorders in India (review, experimental and clinical approach). Int. J. Clin. Pharmacol. Ther. Toxicol. 1988; 26: 176-84.

84. Yamasaki K, Nakano M, Kawahata T, Mori H, Otake T, Ueba N, et al . Anti-HIV-1 activity of herbs in Labiatae. Biol. Pharm. Bull. 1998; 21: 829-33.

85. Renzulli C, Galvano F, Pierdomenico L, Speroni E, Guerra MC. Effects of rosmarinic acid against aflatoxin B1 and ochratoxin-A-induced cell damage in a human hepatoma cell line (Hep G2).J. Appl. Toxicol. 2004; 24: 289-96.

86. Manosroi J, Dhumtanom P, Manosroi A. Antiproliferative activity of essential oil extracted from Thai medicinal plants on KB and P388 cell lines.CancerLett. 2006; 235: 114-20.

87. Mohan L, Amberkar MV, Kumari M. Ocimumsantum L. (Tulsi) - An Overview - A Review Article. Internat. J. Pharmaceu. Sci. Rev and Resear 2011; 7: 51-3.

88. Sandeep Pandey, Phytochemical Constituents, Pharmacological and Traditional Uses of Ocimum gratissimum L in Tropics, Indo Am. J. P. Sci, 2017; 4(11).

89. Iqbal J, Mishra RP. In vitro activity of medicinaplants against some bacterial and fungaisolates. Asian $\mathrm{J}$ Pharm Clin Res 2015;8:225-30.
90. Aziba PI, Bass D, Elegbe Y. Pharmacological investigation of Ocimum gratissimum in rodents Phytother Res 1999;13:427-29.

91. Iwalokun BA, Gbenle GO, Adewole TA, SmithSI, Akinsinde KA, Omonigbehin EO. Effects of Ocimum gratissimum L essential oil at subinhibitory concentrations on virulent and multidrug-resistant Shigella strains from Lagos, Nigeria. APMIS 2003;111:477-82.

92. Ekwenchi MM, Oluigbo J, Akpuaka AAntibacterial activity of $n$-hexane extract of Ocimum gratissimum leaves. IOSR J App Chem 2014;7:6-10. 49.

93. Mann A. Phytochemical Constituents and Antimicrobial and Grain Protectant Activities of Clove Basil (Ocimum gratissimum L.) Grown in Nigeria. Int J Plant Res 2012;2:51-58.

94. Nweze EI, Eze E. Justification for the useof Ocimum gratissimum $\mathrm{L}$ in herbal medicine and its interaction with disc antibiotics. BMC Compl Alter Med 2009;9.

95. Ilori M, Sheteolu AO, Omonibgehin EA, Adeneye AA. Antidiarrhoeal activities of Ocimum gratissimum (Lamiaceae). J Diarrhoeal Dis Res 1996;14:283-85.

96. Pratheeba T, Ragavendran C, Natarajan D. Larvicidal, pupicidal and adulticidal potential of Ocimum gratissimum plant leaf extracts againsfilariasis inducing vector. Int $\mathrm{J}$ Mosquito Res2015;2:1-8.

97. Macdonald IO, Oludare AS, Olabiyi A.Phytotoxic and Antimicrobial activities of Flavonoids in Ocimum gratissimum. Life Sci J 2010;7:45-48.

98. Mahapatra SK, Chakraborty SP, Das S, Roy S.Methanol extract of Ocimum gratissimum protects murine peritoneal macrophages from nicotine toxicityby decreasing free radical generation, lipid andprotein damage and enhances antioxidant protection. Oxi Med Cell Long 2009;2:222-30.

99. Nwanjo HU, Oze GO. Hypolipidaemic and Antioxidant properties of Ocimum gratissimum on Diabetic rats. Plant Prod Res J 2007;11:1-4.

100. Egesie UG, Adelaiye AB, Ibu JO, Egesie OJ. Safety and hypoglycaemic properties of aqueous leaf extract of Ocimum gratissimum in streptozotocininduced diabetic rats. Nigerian J Physiol Sc2006;21:31-35.

101. Nangia-Makker $\mathrm{P}$ et al. Inhibition of breast tumor growth and angiogenesis by a medicinal herb: Ocimum gratissimum. Int $\mathrm{J}$ Cancer2007;121:884-94.

102. Iweala EEJ, Liu $\mathrm{f}$, Cheng $\mathrm{R}$, $\mathrm{Li} \mathrm{Y}$, Omonhinmin CA, Zhang Y. Anticancer and free radical scavenging activity of some Nigerian food plants in vitro. Int $\mathrm{J}$ Cancer Res 2015;11:41-51. 
103. Thomas $\mathrm{N}$ et al. Methanolic crude leaf extracof Ocimum gratissimum reverses phenylhydrazine-induced anemia in albino wistar rats. Niger J ExpClin Bio sci 2013;1:237.

104. Ofem OE, Ani EJ, Eno AE. Effect of aqueousleaves extract of Ocimum gratissimum on hematological parameters in rats. Int J Appl Basic Med Res 2012;2:38-42.

105. Obianime AW, Aprioku JS, Esomonu C. Theeffects of aqueous Ocimum gratissimum leaf extract on some biochemical and hematological parametersin male mice. Asian J Biol Sci 2011;4:44-52.

106. Tripathi RD, Banerji R, Sharma ML, Balasubrahmanyam VR, Nigam SK. Toxicity of essential oil from a new strain of Ocimum gratissimum (Clocimum) against betel vine pathogenic fungi. Agri Bio Chem 1985;49:227782.

107. Hakkim FL, Arivazhagan G, Boopathy $\mathrm{R}$, Antioxidant property of selected Ocimum species and their secondary metabolite content, Journal of M edicinal Plants Research, 2008, 2(9), 250-257.

108. Mwangi PW, Wambugu S, Kariuki DK, Mbugua PM, Kanui TI. Antinociceptive activities of the ethanolic extracts of Ocimum kilimandscharicum baker ex Gürke and Ocimum kenyense ayob. Ex a.j. Paton leaves. IJP. 2012; 3(1): 1-4..

109. Owuor BO, Ochanda JO, Kokwaro JO, Cheruiyot AC, Yeda RA, Okudo CA, et al. In vitro antiplasmodial activity of selected Luo and Kuria medicinal plants. J Ethnopharmacol. 2012; 144:779-81.

110. Runyoro DKB, Ngassapa O, Kachali L, Obare V, Lyamuya EF. Biological activities of essential oils from plants growing in Tanzania. East and Central African Journal of Pharmaceutical Sciences 2010; 12: 85-91.

111. Sarin RV, Narwal S, Bafna PA. Antidiarrheal activity of aqueous extract of Ocimum kilimandscharicum . J Ethnopharmacol. 2013; 148: 223-8.

112. Kumar AA, M ohan M , Haider SZ, Sharma A, Essential oil composition and antimicrobial activity of three Ocimum species from uttarakhand (India), International journal of pharmacy and pharmaceutical sciences, 2011, 3, 223-225.

113. Shinde K, Shinde V, Mahadik K, Gibbons S. Phytochemical and antibacterial studies on Ocimum kilimandscharicum. Planta Med 2010; 76: 412 .

114. Monga J, Sharma M, Tailor N, Ganesh N. Antimelanoma and radioprotective activity of alcoholicaqueous extract of different species of Ocimum in C57BL mice. Pharm Biol 2011; 49(4): 428-36.

115. Jembere B, Obeng-Ofori D, Hassanali A, Products derived from the leaves of Ocimum kilimandscharicum Guerke (Labiatae) as post-harvest grain protectant against the infestation of three major store product insect pests, Bulletin of Entomological Research, 1995, 85,361-367.

116. Mahesh SP, Patil M B, Kumar R, Patil SR, Evaluation of aqueous extract of leaves if Ocimum kilimandscharicum Guerke wound healing activity in albino wistar rats, International journal of pharmtech research coden (USA), 2009, 1, 544-550.

117. Rahman MS, Khan MMH, Jamal MA. Antibacterial. Antibacterial evaluation and minimum inhibitory concentration analysis of Oxalis corniculata and Ocimum sanctum against bacterial pathogens. Biotechonology. 2010;9:533-6.

118. Farivar TN, Fard AHM, Zahedani SS, Naderi M, Moud BS. Anti tuberculosis effect of Ocimum sanctum extracts in in-vitro and macrophage culture. J Medicinal Sci. 2006;6:348-51.

119. Siva M, Shanmugam KR, Shanmugam B, Venkata SG, Ravi S, Sathyavelu RK, Mallikarjuna K. Ocimum sanctum: a review on the pharmacological properties. Int $\mathrm{J}$ Basic Clin Pharmacol 2016;5:558-65.

120. Khan A, Ahmad A, Manzoor N, Khan LA. Antifungal activities of Ocimum sanctum essential oil and its lead molecules. Nat Prod Commun. 2010;5(2):345-9.

121. Kelm MA, Nair MG, Strasburg GM, DeWitt DL. Antioxidant and cyclooxygenase inhibitory phenolic compounds from Ocimum sanctum Linn. Phytomedicine. 2000;7:7-13.

122. Geetha RK, Vasudevan DM. Inhibition of lipid peroxidation by botanical extracts of Ocimum sanctum: In-vivo and in-vitro studies. Life Sci. 2004;76:21-8.

123. Siva M, Shanmugam KR, Shanmugam B, Venkata SG, Ravi S, Sathyavelu RK, Mallikarjuna K. Ocimum sanctum: a review on the pharmacological properties. Int $\mathrm{J}$ Basic Clin Pharmacol 2016;5:558-65.

124. Aruna K, Sivaramakrishnan VM. Anticarcinogenic effects of some Indian plant products. Food Chem Toxicol. 1992;30:9536.

125. Ganasoundari A, Umadevi P, Rao BSS. Enhancement of bone marrow radioprotection and reduction of WR-2721 toxicity by Ocimum sanctum. Mutation Res. 1998;397:303-12.

126. Shetty SS, Udupu S, Udupu A. 
Evalution of antioxidant and wound healing effects of alcoholic and aqueous extract of Ocimum sanctum Linn. In rats evid based complement. Alternat Med. 2008;5:95-110.

127. Govind P, Madhuri S. Medicinal plants: better remedy for neoplasm. Indian Drug. 2006;43(11):869-74.

128. Mediratta PK, Dewan V, Bhattacharya SK, Gupta VS, Maiti S, Sen P. Effect of Ocimum sanctum Linn. On humoral immune responses. Indian J Med Res. 1998;87:384.

129. Godhwani S, Godhwani JL, Vyas DS. Ocimum sanctum a preliminary study evaluating its immunoregulatory profile in albino rats. J Ethnopharmacol. 1988;24:1938

130. Sridevi G, Gopkumar P, Ashok S, Shastry CS. Pharmacological basis for antianaphylactic, antihistaminic and mast cell stabilization activity of Ocimum sanctum. Inetrnet J Pharmacol. 2009;7.

131. Ravindran R, Devi RS, Samson J, Senthilvelan M. Noise stress induced brian neurotransmitter changes and the effect of
Ocimum sanctum (Linn) treatment in albino rats. J Pharmcol Sci. 2005;98:354-60.

132. Asha MK, Prashanth D, Murali B, Padmaja R, Amit A. Anthelmintic activity of essential oil of Ocimum sanctum and Eugenol. Fitoterapia. 2001;72(6):66970.

133. Jaggi RK, Madaan R, Singh B. Anticonvulsant potential of holy Basil, Ocimum sanctum Linn. And its cultures. Indian J Exp Biol. 2003;41:1329-33

134. Sood S, Narang D, Dinda AK, Maulik SK. Chronic oral administration of Ocimum sanctum Linn augments cardiac endogenous antioxidants and prevents isoproterenolinduced myocardial necrosis in rats. J Pharm Pharmacol. 2010;57:127-33.

135. Joshi H, Parle M. Evalution of nootropic potential of Ocimum sanctum Linn. In mice. Indian J Exp Biol. 2006;44:133-6.

136. Komal S, Verma RJ. Protection against butyl phydroxybenzoic acid induced oxidative stress by Ocimum sanctum extract in mice liver. Acta Poloniae Pharmaceutica Drug Resear 2012;69(5):865-70. 